INTERNATIONAL JOURNA L OF EDUCATION, INFORMATION TECHNOLOGY AND OTHERS (IJEIT)

https://jurnal.unibrah.ac.id/index.php/IJEIT

Vol. 2, No.2, December 2019
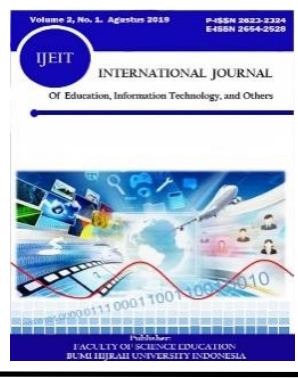

\title{
RELIGIOUS-BASED COMMUNITY AND CONCERN ON MARINE ISSUE: THE PROTESTANT CHURCH OF MALUKU EXPERIENCES
}

\author{
Nancy N. Souisa ${ }^{1}$, Steve G. C. Gaspersz ${ }^{2}$, Fabian N. J. Souisa ${ }^{3}$ \\ Faculty of Theology, Universitas Kristen Indonesia Maluku ${ }^{1,2}$ \\ Polytechnic of Fishery, Langgur-Tual ${ }^{3}$
}

Email: nsouisa@yahoo.com

\begin{tabular}{l}
\hline Article Info \\
\hline Article History: \\
Received: November 20, 2019 \\
Revised: November 29, 2019 \\
Published: December 31, 2019 \\
\hline e-ISSN: 2623-2324 \\
p-ISSN: 2654-2528 \\
\hline DOI: 10.5281 /zenodo.3603559
\end{tabular}

\section{Article Info}

Article History:

Received: November 20, 2019

Published: December 31, 2019

e-ISSN: 2623-2324

DOI: $10.5281 /$ zenodo.3603559

\begin{abstract}
:
This article focuses on the roles of religious communities within particular social contexts which concern on environmental sustainability. On the one side, it contains a holistic notion, i.e. interconnection of all living fields and living beings with their milieu. It proves that religion's values to communal practices demonstrate a concern for natural sustainability. On the other side, the dynamic of such interest toward environmental sustainability influences a critical exploration and even transformation of religious values. Among religious communities, in Maluku context, the Protestant Church of Maluku (Gereja Protestan Maluku$G P M)$ is a Christian community that deliberately and systematically struggles on the problem of environmental sustainability by its religious values (Christianity).
\end{abstract}

Keyword: Religious value, Community development, Archipelago society

\section{INTRODUCTION}

The dialectics in the concept of sustainable development is not only known at present but it has been a problematic long-term issue of the traditional communities' life. The emphasis may not be quality between the "development" and the "sustainable" dimensions. It is precisely because of this difference in emphasis that the world community receives from social virtues maintained in the socio-cultural dynamics, even though the political dynamics place local people in a marginal position.

The religious community, in this case, Christians on the remote areas, are in the communities and, therefore, all dynamics are an internal part of the dynamics of society. Its role appears in the form of initiative or response in the ordinary life of the community. Sometimes one identity becomes projective when his/her role is active and continues to breakthrough social changes. These 
breakthroughs were chosen with various consequences that can be interpreted from different perspectives (Gaspersz \& Souisa, 2018).

In other contexts, one identity has been characterized by resistance against certain cultural hegemony. The religious community takes the right overlap place with marginalized groups, for example, churches in areas targeted for natural resource exploitation, moneylenders and underprivileged in supporting infrastructures such as roads, electricity, health and education services. Humans and their nature become targets and objects whose voices are not heard or heard falsely. In this context, the local community or congregation and their natural resources have the potential to be victims. Then, the inevitable role of the religious community is its role in assisting a community in dealing with the dilemmas of environmental conservation, development projects and the sustainability of nature.

In other words, for the present of Maluku context, the Protestant Church of Maluku (Gereja Protestan Maluku - GPM) build the perspective that the sustainability of nature is related to the responsibilities of the religious community. The functional religiosity in the realm of life is based on the dialectics of principles/values and practices of living.

\section{LITERATURE STUDY}

\section{The GPM Community: It's Existence in The Larger Society}

The Christian community referred to in this article is the community of the Protestant Church of Maluku or GPM. Christian communities in Maluku (and few in North Maluku Province) are mostly members of the GPM. Commonly, one village community is one congregation of GPM, so that they have a double identity as a social and religious community at the same time. Approximately, eighty percent of these religious communities or congregations live in rural areas as coastal and mountainous. The rest exists in urban areas, especially some newly established districts.

Historically, the Christian communities in Maluku were established by many Dutch mission organizations and once ordered by the Dutch colonial government as the Indische Kerk. After being colonized by the Dutch for hundred years, the Christian communities in Maluku established the new independent church in 1935 namely the Protestant Church of Maluku (GPM). Since then, it has been organizing itself as the biggest church in Maluku until today (Tapilatu, 1992). During 83 years (19352018) the GPM consolidates itself with its independence principles: potential, funding, and theology. The independence runs with other communities and the government.

The GPM community remains in an on-going process to develop its contextual self-existence by accepting and responding to social changes and criticisms from various perspectives and parties. On the other hand, however, the church continuously is doing self-reform and steps forward for development and independence in many fields and levels (RIPP/PIP GPM 2016-2025: 3-8). The church development is based on assessment and analysis that each congregation of GPM experiences different levels of growth (cultural-social-economic) in the context of the archipelago so that it needs a well-organized ministry plans and actions.

\section{The Development of Religious Values and Praxis on Marine Issue}

The dynamic context of the archipelago communities and their worldviews, which is the GPM service areas, affects the understanding of the natural environment, especially about inter-relationship between sea, land (island), human and God. Their social-cultural worldviews and Christianity-based religious traditions are different to those who live in as a continental community. The former takes seriously sea-island context as the basis for their religious tradition; the latter is not paying attention for the context as serious as the former. For example, the continental community or congregation is more concern of the land as it has been shown by the biblical texts. That is the reason one can read somehow a negative indication of the sea in Christian religious texts since the context of Hebrew society in the Old Testament and early Christianity in the New Testament have strong emphasis and orientation to land and mountain (Lilburne, 1989). Those religious texts reflect the contextual worldview of the authors at that time.

Differently, the Christian communities of GPM have a positive theological understanding about sea-island context because they live in such an archipelago environment. For sure, that theological 
understanding affects their ways to reinterpreting such religious texts and in constructing marinebased Christian tradition in Maluku. In that ways, they recognize that Christian values are open to accepting contextual theological perspective that understands the sea (ocean) and archipelago have an essential value for strengthening their spiritual life as islanders; and human beings are part of the ecosystem that giving respect for other ecosystems as well as bearing responsibility for the better life of the universe.

As such, at the local basis, the GPM over and over implements many social projects to build welfare communities based on church management on the marine issue. For years, the church struggles for maintain archipelago environment from devastating impacts of the national development projects and encouraging its congregations to produce things by using natural resources wisely so that nature can support human life sustainably.

Conceptually, as the religious institution, GPM had introduced theological perspectives as the basis for developing theological praxis of its congregation that looking at the archipelago environment as vital resources for living together in Maluku. These perspectives distributed by church's publication about its existence as the archipelago church, and then accentuated the issue of justice, peace, and integrity of creation for arranging church's planning in every congregation (Gaspersz, Maspaitella, \& Takaria, 2015).

In 1997, UKIM, the Christian university of GPM, launched the new theological graduate program "Religion and Culture." Supported by some outstanding professors of Universitas Pattimura, this graduate program introduced theoretical concepts and research projects on coastal communities such as "anthropology of coastal society," "marine theology," "adat-law of indigenous islanders," and "biblical hermeneutics on marine." These academic perspectives triggered some critical researches on issues of marine, community-based management of coastal society, and spirituality of the indigenous islanders.

In line with the dynamics of the Maluku society which opens toward possibility to be mistreated in the exploitation of natural resources, GPM has struggled with maritime problems as the church's problems as well, and the involvement of professional church members in their education and employment fields (Tuhepaly, 2006). In 2013, GPM institutionally created a special commission to investigate and discuss environmental issues, including maritime. The critical momentum is in the development of the Master Service Pattern (PIP) and the Service Development Plan (RIPP) 20162025, in which the archipelago context becomes the primary concern. In 2016, GPM issued the Advocacy Guidelines as a strategy of community-based development. Then, in 2017, GPM determined its theme for church's services as "Together in Advocating Rights for Life of Human Beings and Nature for Increasingly Quality Living." So, by the service theme, all concerns and programs are directed to creative inter-relationship between human beings and creatures on the earth, including marine affairs.

By those church's service design and strategy, the GPM applies a praxis approach. In this approach, one community connects many values and practices in an unfinished moving spiral formation. The evaluation toward communities' works as well as natural and social-cultural developments, leads to a real faith reflection and dissatisfaction with abstract propositions socialized in mere rituals. By this approach, the congregations read, study, live and work within the real archipelago context as their sacred text to strengthen their spirituality and practical life.

\section{RESEARCH METHODS}

This article uses interdisciplinary qualitative methods such as social hermeneutics, the phenomenology of religion, and cultural anthropology. We collected data from various documents and field-research notes related to the primary theme. Then, it is interpreted through social hermeneutics to discover inter-link between concepts and theoretical reflections. Religious texts are primary documents that frame Christian traditions of faith and church.

\section{RESEARCH RESULT}

\section{Transformative Massive Movement}


By implementing the model of centralizing vision and decentralizing initiatives, the Christian religious community (church members of GPM) initiated simultaneously environmental awareness movement. As a result, the attention of its congregations is increasing to understand a culture, nature, and its theological concern at once.

Organizational consolidation has made local contents in each congregation and church districts (klasis) become valuable resources and deserve serious attention. Environmental issues from every service area of GPM in North Maluku, Central Maluku, Ambon City, Southeast Maluku, WestSoutheast Maluku, and Southwest Maluku as GPM service areas and the identity of the congregations faced together and in togetherness.

In the archipelago context of Maluku, it has specific difficulties such as the financial issue in dealing with communication and coordination among congregations. Self-reliance (internal) is not aligned directly with the extent of the area and many environmental problems to be handled. The greatest strength is still the commitment of the people who reflect their spiritual experience and Christian faith not only based on religious ceremonies but further on practical-contextual communal life beyond an individual's spirituality manners. Another potential strength is the network and organizing system which still proves quite useful in matters of communication and consolidation (Tahitu, Bakarbessy, \& Lawalata, 2016).

\section{a. Community Activities for Nurturing Nature}

Some data about community's movements include:

1. Maintaining local wisdom on environmental conservatory. Participation and reinterpreting contextually cultural mechanism for keeping natural resources namely "sasi." In general, there are two types of sasi, [1] sasi laut (sea sasi) and [2] sasi hutan (forest sasi). Sasi is a kind of traditional rule to prohibit people from taking all things (fish, fruit) during certain periods to give time for nature recovering itself and keeping its sustainability. This practice is common in various regions in Maluku.

2. The grass-root groups also have their efforts for environmental advocacy, such as make a team, i.e. environmental care team.

3. Building cooperation with related parties to socialize and actively care for the environment such as group called "Green Maluku," Universitas Pattimura, government (district and province levels, police department on district and province levels, etc. The cooperation in the form of socialization and action on trash management, the coastal cleaning from special plastic waste, etc.

4. The congregations work actively to overcome various environmental problems that occur around residential areas and the surrounding islands/sea strategically, such as:

a. Provide bulletin and poster to educate people not to dispose of garbage on the beach/sea.

b. Building a commitment to not using plastic container, especially in the church ceremony and ritual.

5. The conscious movement is emerging strongly for trash management that pollutes the sea and river environments. They initiate and manage voluntary works weekly to clean sea and land environment, recycling plastic garbage. Competition of "clean parish" among congregation in certain region/district.

6. Increased awareness of managing the potential of marine resources sustainably, such as fish, coral reefs, mangrove, etc.

7. There are many efforts to build sensitivity to disasters.

\section{b. Activities for Developing Reflections on Marine Theology as Christian Spirituality of Maluku Islanders}

In various documents, the development of marine discourse is quite intensive. It is running among others in the routine church activities, such as community spiritual-practical formation. It applies 
formal education method, discussion, Bible study, meditation, theological reflection, training, seminar, workshop, etc.

The approach taken by GPM is entirely integrated, in terms of the target and subject of guidance starting from children, adolescents, youth, men, women to the elderly, professional groups, group of families (unit), group of units (sector), congregations, group of congregations in particular region (klasis), and even as ecumenical group of various Christian denominations.

\section{c. Academic Writings that link Religious and Marine Reflections}

Actually, some writings show concern on maritime affairs from various disciplines carried out by GPM church members. However, due to the limitations of the study, this paper only focuses on some theological-based academic writings that review the maritime issue. They have been written by students of the theology and Christian religious education study programs both of the undergraduate and graduate, also by the lecturers. They raised some themes as below:

1. Aru women and wakat in Aru Island

2. Sasi from the perspective of biblical studies and religious education

3. Marine Theology

4. Theology of Archipelago

5. Theological Reflections on the Economic of Coastal Communities

6. Theological Reflections on Belang (traditional boat) and cosmology of the Islanders.

In addition to the writings, explicitly and independently there is also an integrative approach, which concerns on the marine issue was discussed as part of the course. At least, in the Faculty of Theology UKIM Ambon, there is a new consciousness to dig several social, cultural, and economic issues from inter-disciplinary, multi-disciplinary and trans-disciplinary paradigms. Some subjects that discuss marine affairs, namely "The Archipelago Transformative Christian Education", "Public Theology", "Contemporary Christian Religious Education", "Christian Religious Education of the Faith Community", "Anthropology of Coastal Society", "The Rights of Indigenous Peoples", "Contextual Theology", "Social Research Methods", "Biblical Contextual Theology", "Congregational Studies", "Ecclesiology", "Sociology", and "Citizenship and Multiculturalism". Through the new kind of subjects, it can be developed a critical academic worldview related to sea and island which in turn determining progressive development project on religion, culture and society in the archipelago.

\section{The Correlation of Sea-Island Perspective and Religious Discourse}

Religious tradition - especially Christianity - has influenced the interaction among human beings with their environment (sea and land) in Maluku. It formed somehow an ambiguity between the ways to interpret the meaning of the Christian tradition for human life in the context of the archipelago. On one side, there is discontinuity with traditions that giving priority to land, more emphasis on human beings, God's transcendence, a notion that sea is the threat, deadly space, and interpretations of the societal context and its Christian values. On the other hand, there is continuity, where nature regarded having sacred meanings because created by God, human and nature relationship is in the way of mutual respect and good order, God who involves creatively and sustainably within human history and natural environment.

The pattern of relationship that often ignored is relations that enriched by natural revelation in its existence. Nature becomes a subject that controls or directs social change. Natural phenomena affect the way of thought and changing many things, even societies. Human and nature relations situated within a pattern of correlation as part of the ecosystem. Science has discovered many things that could be subject of dialogue at the level of faith that is often creating an epistemological and theological gap between science and faith.

Marine theology is unfolding the blind spot of continent-based theology that has been influencing many ways of how Christians build their culture, tradition, and civilization. Paradigmatically, it can be seen as a new direction for constructing existential meaning and relations that produce new sacred spiritual texts which provide living horizons. Searching for the ultimate will of God in the universe and also in the creative interrelationship of human and nature (sea and land) as archipelago society. 
The cosmic relationship becomes existential media to bridge a gap created by world religions about human and nature.

Social and natural life determined by spiritual and social aspects related to religious values. Religious contributions that should be encouraged continuously are functional sacred spaces for the inclusive humanity and unity with the natural environment wisely. It is a place where the tipping point brings into the middle stream of religious discourse in the events and scientific studies such as marine studies.

\section{Marine Theology as Praxis Spirituality}

Discourse on marine theology in principle is the foundation for conducting concrete actions in the daily life of the archipelago society. By this marine theology, Christian communities are invited to see that human-nature (sea-land) relationship is not merely an instrumental economic manner. The relationship should be understood and lived on as basis for concrete actions such as keeping coastal environment clean, increasing awareness to stop using plastic materials that implies plastic wastes threatening coastal (sea and land) ecosystem, organizing proper resettlement that respect to sea environment and not assuming sea as the "giant dump" where people can throw everything in it.

Programmatically, activities to conserve natural environment may be conducted through "kewang" training program (kewang means environment guard, as part of traditional village administration) that is not only giving technical skills but grounded by theological principle about a cosmic relationship of God, human and nature. In some congregations, theological principles of marine theology encourage to increase technical skill for recycling plastic wastes into house ornaments, souvenirs, and home industry that bring economic advantage for Christian families of GPM congregations.

All things to do should be understood reactively toward the threat of environmental devastation of sea and island but as critical efforts to respect our archipelago environment as the "universe home" that provide convenience, security, peace, and justice sustainably for all creatures on the earth. Therefore, that marine theology must be the basis for doing works on sustainable environmental development and daily activities of coastal society to conserve continuing their life in the islands of Maluku. At that point, marine theology is not an abstract theological concept but a praxis spirituality which is inspiring people to work in balance with environmental sustainability.

\section{CONCLUSION}

The research about maritime context must be conducted through inter-, multi-, and transdisciplinary approaches. The maritime setting does not only provide data to be managed through quantitative methods but has to consider seriously to use quantitative methods. Interdisciplinary approaches unfold more complex problematic situation about the maritime context where cultural dimension and human action concerning natural environment will determine the development process that occurs in the coastal society of Maluku.

This article is an academic reflection based on theological scientific perspective utilizes the various theoretical framework of philosophy (social hermeneutics), religious studies (phenomenology of religion), and cultural anthropology. These three theoretical frameworks are combined critically to comprehend maritime context from the cultural dimension and the impact of development programs that more conducted on the basis of continental rather than maritime or archipelago worldviews.

The implication of continental-based development approaches is the ignorance toward cultural and religiosity dimensions of the archipelago communities. Instead, they are doing daily activities by cultural and religious worldviews that both determined by existential relations between human and natural environment (sea and land). The article finally attempts to make a roadmap to analyzing maritime context from the side of religious community existence.

\section{REFERENCE}

Gaspersz, S., Maspaitella, E., \& Takaria, M. (Eds.). (2015). Delapan Dekade GPM Menanam, Menyiram, Berbuah dan Bertumbuh. Salatiga: Satya Wacana University Press. 
Gaspersz, S., \& Souisa, N. N. (2018). The Welfare-Based Development in The Context of Maritime Culture: Encounters with anthropological perspective The Welfare-Based Development in The Context of Maritime Culture : Encounters with anthropological perspective.

Lilburne, G. R. (1989). A Sense of Place: A Christian Theology of the Land. Nashville: Abingdon Press.

Tahitu, A., Bakarbessy, D., \& Lawalata, C. (Eds.). (2016). Eksistensi Masyarakat Kepulauan Mengkomunikasikan Kesejahteraan (Pendekatan Interdisiplin). FISIP UKIM Press.

Tapilatu, M. (1992). Sejarah Gereja Protestan Maluku. Sekolah Tinggi Teologi (STT) Jakarta.

Tuhepaly, D. K. (2006). Otonomi Khusus Bidang Kelautan. Yogyakarta: Galang Press. 